\title{
Cytological Observations on Some East-Himalayan Monocots
}

\author{
P. N. Mehra and S. K. Sachdeva \\ Department of Botany, Panjab University, Chandigarh, India
}

Received July 1, 1977

The Himalayas inhabit a fairly large number of representatives of the various monocotyledonous families, its eastern wing being comparatively much richer than the western (cf. Hooker 1894). Our previous communications in this journal provided cytological information on some W. Himalayan monocots (Mehra and Sachdeva 1975a,b; 1976a-e). The present paper deals with 21 taxa belonging to 18 species from the eastern part.

\section{Material and methods}

The materials were collected from the wild in the hills of Darjeeling and Gangtok. Voucher specimens have been deposited in the Herbarium of the Department of Botany, Panjab University, Chandigarh. The methods followed were the same as described earlier (Mehra and Sachdeva 1976a).

\section{Results}

Table 1 lists the species, their chromosome numbers and the specific localities from where they were collected. Only interesting features in some of the genera are described below:

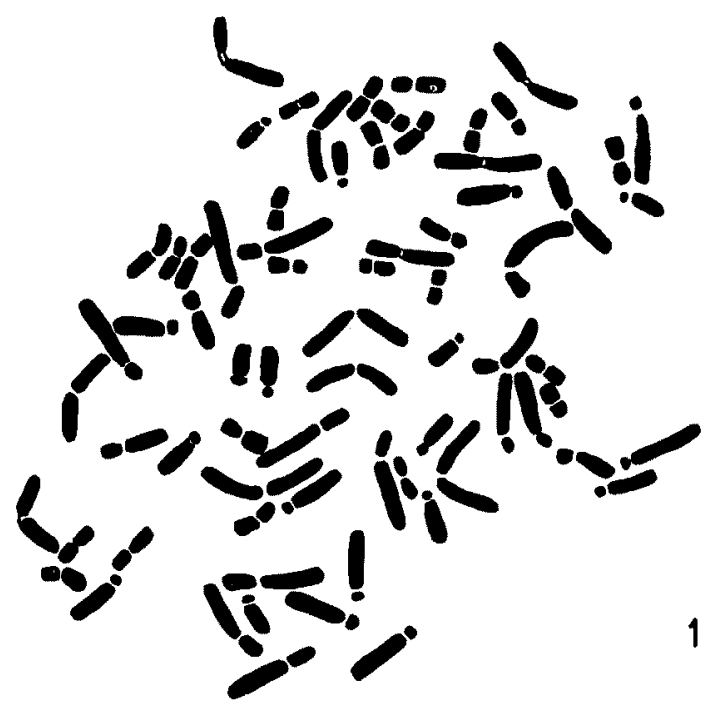

Fig. 1. Smilacina fusca, $2 n=72$ in root-tip cell. $\times 1500$. 


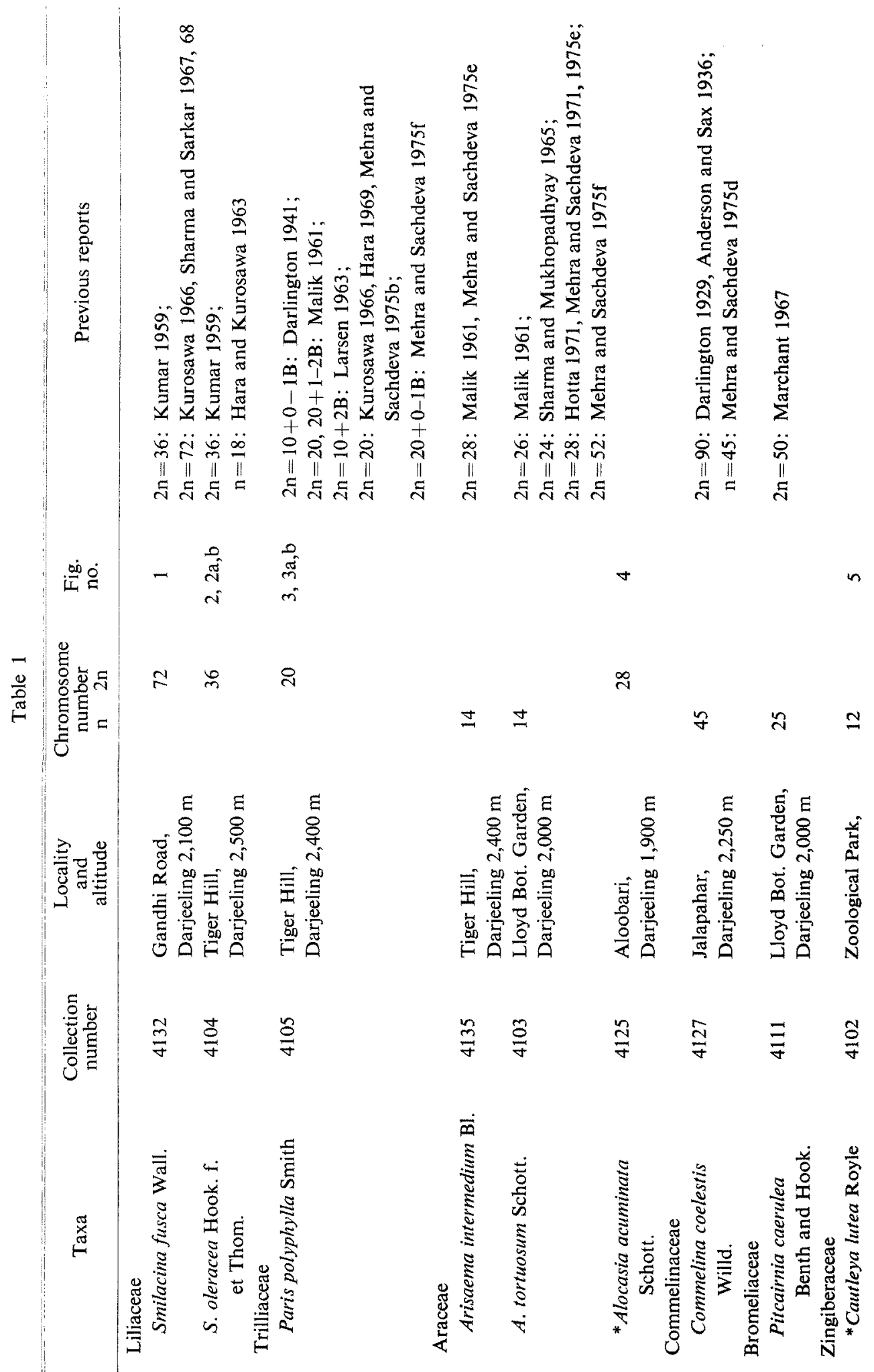




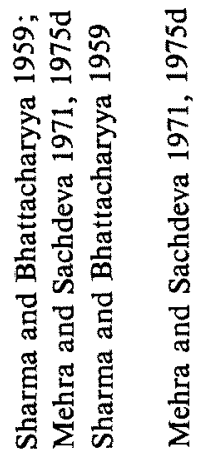

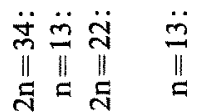

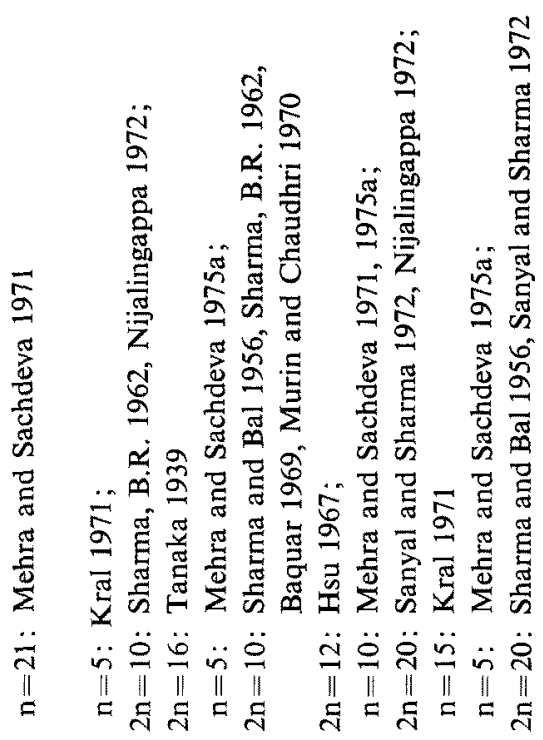

$\sigma \therefore=\simeq$

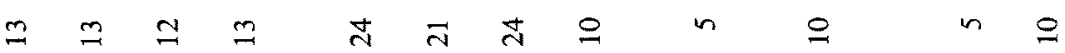

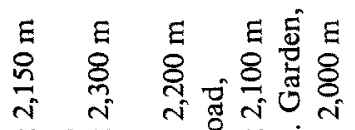

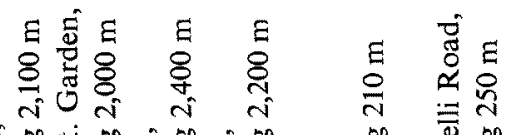

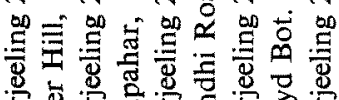

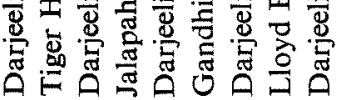

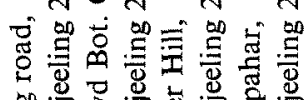

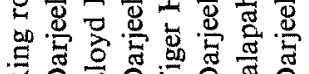

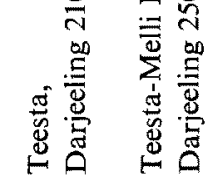

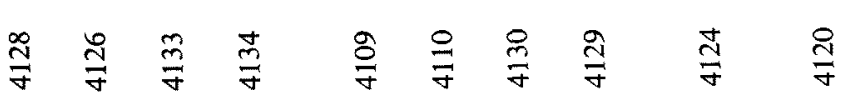

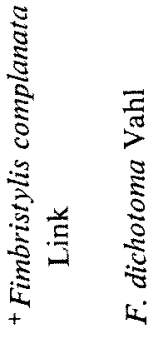

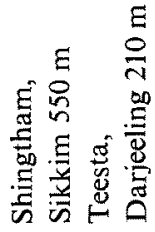

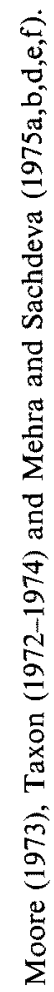



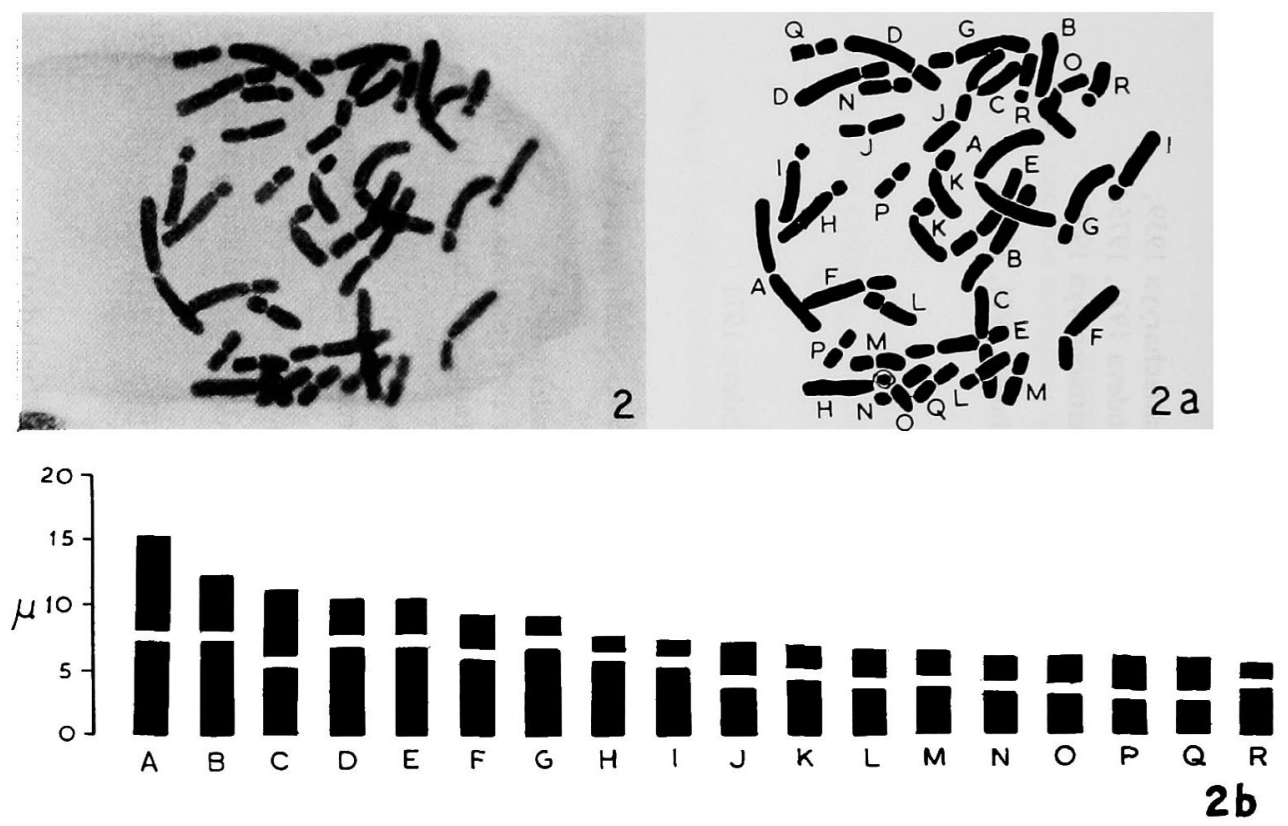

Figs. 2, a, b. 2, Smilacina oleracea, $2 \mathrm{n}=36$ in root-tip cell. $\times 1500.2 \mathrm{a}$, explanatory diagram to Fig. 2. 2b, idiogram.

Smilacina. Two species, S. oleracea $(2 \mathrm{n}=36$; Figs. $2,2 \mathrm{a}, \mathrm{b})$ and $S$. fusca $(2 n=72$; Fig. 1), were studied. $S$. oleracea possessed four pairs of median, ten pairs of submedian, and four pairs of subterminal chromosomes (Fig. 2b). Secondary constrictions were not noticed in any of the pairs. Chromosome size ranged between $15 \mu$ to $5 \mu$. The karyotype of S. fusca (Fig. 1) agrees with that described by Kurosawa (1966) i.e. it consisted of eight pairs of median, sixteen pairs of submedian, and twelve pairs of subterminal chromosomes. Chromosome size ranged between $12 \mu$ to $3 \mu$.

Paris. P. polyphylla was found to possess $2 \mathrm{n}=20$ (Figs. 3, 3a,b). The karyotype consisted of two pairs (A, B) of median, four pairs (C, D, E, F) of submedian, and four pairs $(\mathrm{G}, \mathrm{H}, \mathrm{I}, \mathrm{J})$ of subterminal chromosomes. Pairs $\mathrm{C}$ and $\mathrm{J}$ were found to be heteromorphic (Fig. 3b). The West-Himalayan taxon of this species previously worked out by us (Mehra and Sachdeva 1976a) had revealed several pairs to be heteromorphic though the same basic karyotype of two pairs of median, four pairs of submedian and four pairs of subterminal chromosomes was manifested. It would be appropriate to mention that karyotype polymorphism has been observed by us earlier in Trillium govanianum (Mehra and Sachdeva 1976a) and Allium victorialis (Mehra and Sachdeva 1976b).

Cautleya. C. lutea has been investigated for the first time. Two cytological races with $n=12$ and $n=13$ were found to occur in Darjeeling hills (Figs. 5, 6). Meiosis in both the taxa was found to be normal. Plants with $n=13$ were shorter, possessed small-sized leaves and bracts and had lesser flowers per spike, in comparison to plants with $n=12$. However, the size of the flower was almost the same in both the cases. It may be pointed out that the plants with $n=13$ were 
always found to be occurring at higher altitudes $(2,250-2,500 \mathrm{~m})$ in contrast to those with $\mathrm{n}=12$ which occurred between $2,000-2,200 \mathrm{~m}$.

With regard to C. spicata, Sharma and Bhattacharyya's (1959) report of $2 \mathrm{n}=34$ appears to be erroneous as our present investigation from the same area from where they studied this species showed $n=13$ (Fig. 7). Our previous study of this species from the West-Himalayas had also revealed $n=13$ (Mehra and Sachdeva 1976c).
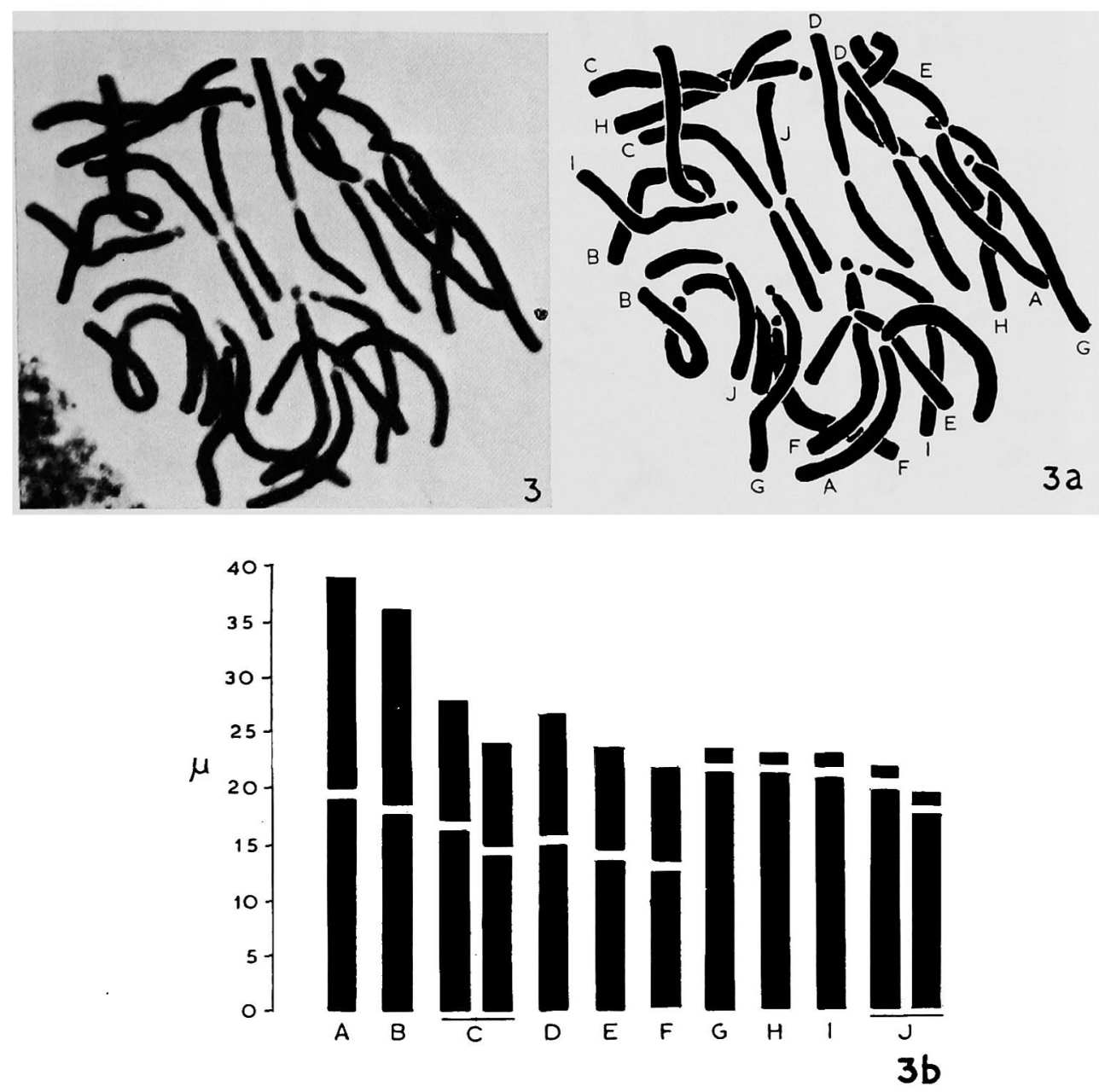

Figs. 3, a, b. 3, Paris polyphylla, $2 \mathrm{n}=20$ in root-tip cell. $\times 1500$. 3a, explanatory diagram to Fig. 3. $3 \mathrm{~b}$, idiogram.

Globba. G. hookeri showed $\mathrm{n}=12$ (Fig. 8). The present report differs from that of Sharma and Bhattacharyya (1959) who observed $2 n=22$ in the root-tip cells of this species.

Carex. Two of the three species of Carex, C. insignis $(\mathrm{n}=24$, Fig. 9) and $C$. longipes $(\mathrm{n}=21$, Fig. 10) provide the first cytological reports for the species. $C$. filicina showed $\mathrm{n}=24$ (Fig. 11). However, the West-Himalayan taxon of this 
species worked out from Nainital hills had revealed a count of $n=21$ (Mehra and Sachdeva 1971) indicating the presence of cytological races in this species. The role of polyploidy and aneuploidy in the evolution of various species of this genus

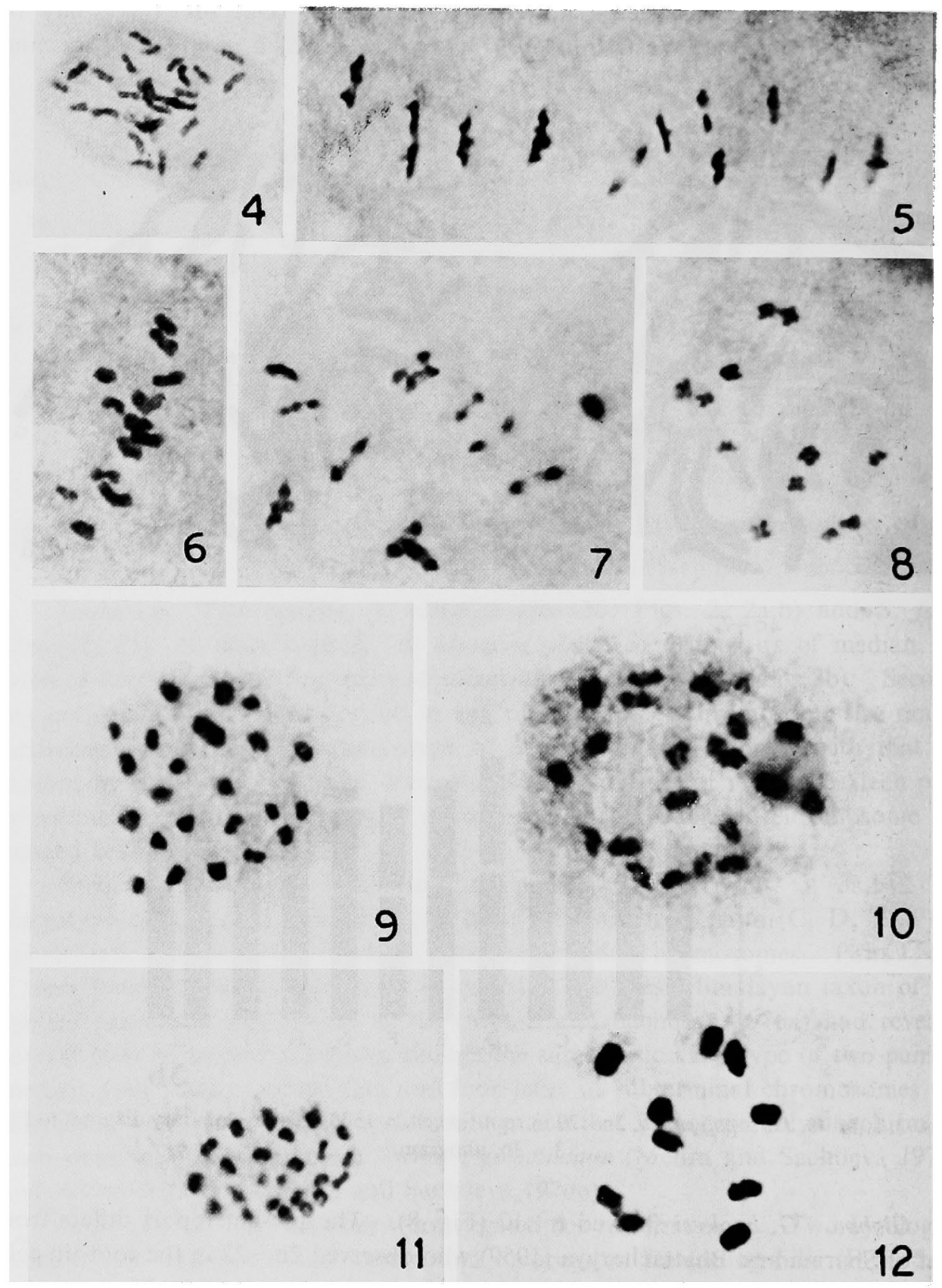

Figs. 4-12. 4 , Alocasia acuminata, $2 \mathrm{n}=28$ in root-tip cell. 5, Cautleya lutea, $\mathrm{n}=12$ at $\mathrm{M}_{1}$. 6 , C. lutea, $\mathrm{n}=13$ at $\mathrm{M}_{1}$. 7, C. spicata, $\mathrm{n}=13$ at $\mathrm{M}_{1}$. 8, Globba hookeri, $\mathrm{n}=12$ at $\mathrm{M}_{1} ; 9$, Carex insignis, $\mathrm{n}=24$ at $\mathrm{M}_{1} .10, C$. longipes, $\mathrm{n}=21$ at diakinesis. $11, C$. filicina, $\mathrm{n}=21$ at $\mathrm{M}_{1}$. 12 , Fimbristylis complanata, $\mathrm{n}=10$ at $\mathrm{M}_{1}$. All $\times 1500$. 
has already been discussed by us previously (Mehra and Sachdeva 1975).

Fimbristylis. The present reports for $F$. dichotoma $(\mathrm{n}=5,10)$ and $F$. diphylla $(n=5,10$; Fig. 13) agree with the observations of the various authors mentioned in Table 1. It is seen that both diploid and tetraploid races of these two species are quite common in the Eastern as well as in the Western Himalayas. However, Kral

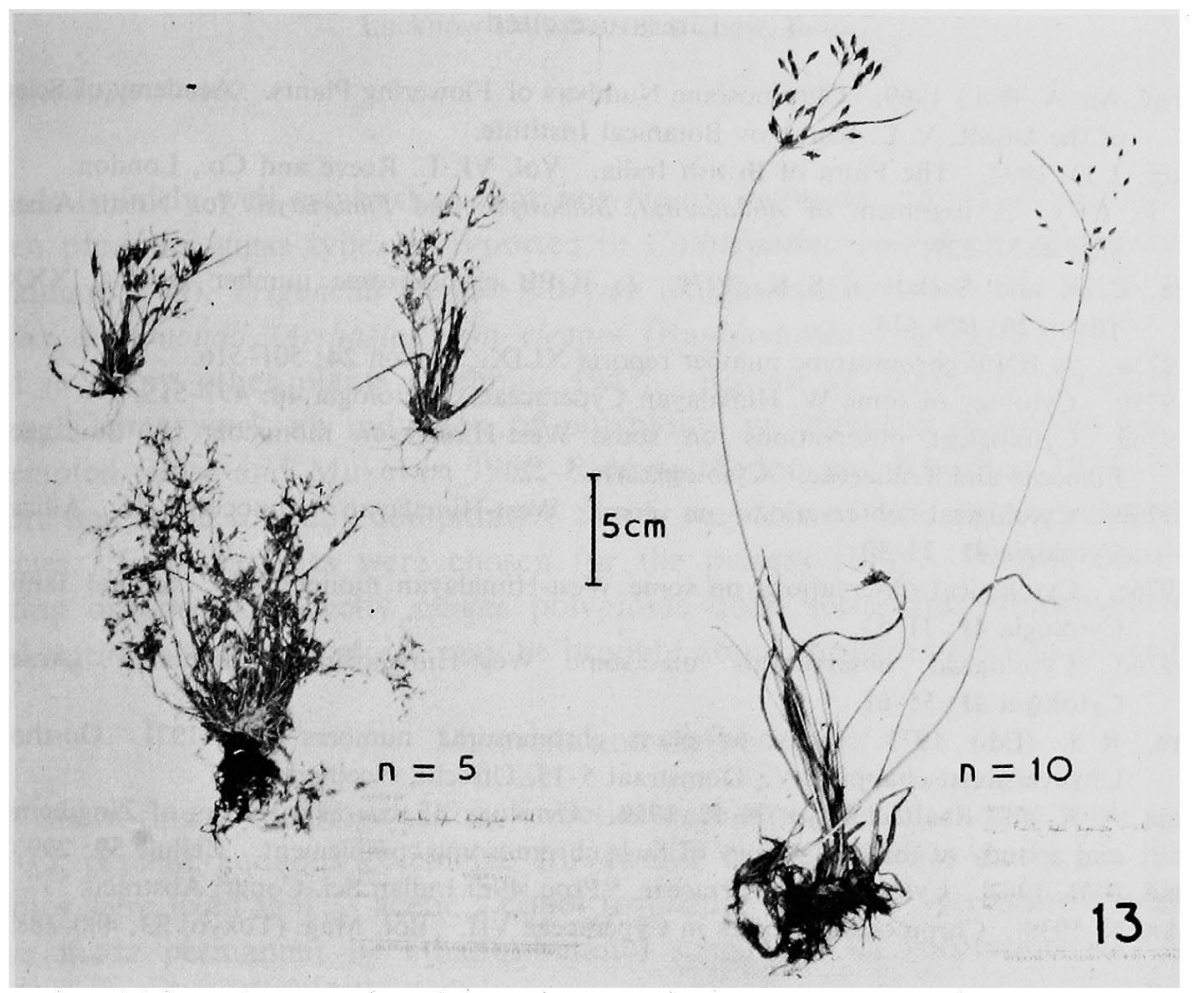

Fig. 13. Fimbristylis diphylla, cytotypes with $\mathrm{n}=5$ and $\mathrm{n}=10$.

(1971) reported the occurrence of hexaploid race from North America. F. complanata $(\mathrm{n}=10$, Fig. 12) was found to be occurring at tetraploid level in Darjeeling hills. Diploid forms of this species were earlier reported by Sharma, B. R. (1962) from North India and by Kral (1971) from North America. Tanaka (1939) had, however, observed $2 n=16$ in this species.

\section{Summary}

Twenty one taxa belonging to 18 species of monocots are studied. Four species i.e. Alocasia acuminata $(2 \mathrm{n}=28)$, Cautleya lutea $(\mathrm{n}=12,13)$, Carex insignis $(\mathrm{n}=24)$ and $C$. longipes $(\mathrm{n}=21)$ are investigated for the first time. New chromosome numbers are reported for another three species, namely, Globba hookeri $(\mathrm{n}=12)$, Carex filicina $(\mathrm{n}=21)$ and Fimbristylis complanata $(\mathrm{n}=10)$. Heteromorphic chromosome pairs are noticed in Paris polyphylla $(2 \mathrm{n}=20)$. 


\section{Acknowledgements}

Financial assistance from U.S. Department of Agriculture under a PL 480 Project (Grant No. FG-In-482) to the senior author is gratefully acknowledged. Our thanks are also due to Head of the Division of Botany, F. R. I. Dehradun for the help in the identification of voucher specimens.

\section{Literature cited}

Federov, An. A. (Ed.) 1969. Chromosome Numbers of Flowering Plants. Academy of Sciences of the USSR, V. L. Komarov Botanical Institute.

Hooker, J. D. 1894. The Flora of British India. Vol. VI. L. Reeve and Co., London.

Kral, R. 1971. A treatment of Abildgardja, Bulbostylis and Fimbristylis for North America. Sida 4: 57-227.

Mehra, P. N. and Sachdeva, S. K. 1971. In IOPB chromosome number reports. XXXIII. Taxon 20: 609-614.

-. 1975a. In IOPB chromosome number reports XLIX. Taxon 24: 501-516.

-. 1975b. Cytology of some W. Himalayan Cyperaceae. Cytologia 40: 497-515.

-. 1976a. Cytological observations on some West-Himalayan monocots II. Smilacaceae, Liliaceae and Trilliaceae. Cytologia 41: 5-22.

-. 1976b. Cytological observations on some West-Himalayan monocots III. Alliaceae. Cytologia $41: 23-30$.

-.1976c. Cytological observations on some West-Himalayan monocots IV. Several families. Cytologia 41 : 31-53.

-. 1976d. Cytological observations on some West-Himalayan monocots V. Araceae. Cytologia 41 : 55-61.

Moore, R. J. (Ed.) 1973. Index to plant chromosome numbers 1967-1971. Oosthoek's Uitgeversmaatschappij B.V., Domstraat 5-13, Utrecht, Neetherlands.

Sharma, A. K. and Bhattacharyya, N. K. 1959. Cytology of several members of Zingiberaceae and a study of the inconstancy of their chromosome complement. Cellule 59: 299-345.

Sharma, B. R. 1962. Cytology of Cyperaceae. Proc. 49th Indian Sci. Congr. Abstracts 337-338.

Tanaka, N. 1939. Chromosome studies in Cyperaceae VII. Bot. Mag. (Tokyo) 53: 480-488. 